\title{
THE EFFECT OF DISPOSABLE BED BATHING (DBB) ON NURSE SATISFACTION AND THE COMFORT OF STROKE PATIENTSIN WAHIDIN SUDIROHUSODO HOSPITAL
}

\author{
Titi Iswanti Afelya ${ }^{1 *}$, Rosyidah Arafat $^{2}$ \\ ${ }^{1,2}$ Universitas Hasanuddin \\ Email*: afelyatiti.1010@gmail.com
}

\begin{abstract}
Introduction: Bathing is one of the main responsibilities of a nurse, but this is still not done routinely because of the bathing procedure using water and a basin (conventional) takes a long time for each patient. The study aimed to determine the effect of disposable bed bathing method on Nurse satisfaction and the comfort of stroke patients at public hospital in Makassar. Methods: This research was a quasi-experimental design with post-test with control group. The subjects were divided into two groups, they were intervention group given disposable bed bathing and the control group. Results:disposable bed bathing method increased the nurse satisfaction ( $p=$ 0.029), but did not affect to the comfort perceived by the patient ( $p=0.063)$. Conclusions: Disposable bed bathing method increases nurse satisfaction in bathing patients but there is no effect on patient comfort, because bathing habits using water is an inherent culture for patients.
\end{abstract}

Keywords: nurse satisfaction, comfort, bed bathing, stroke.

\section{INTRODUCTION}

Stroke is one of the main causes the disability. About 50 million stroke patients worldwide had physicalexperience, cognitive and emotional problems, and $24-74 \%$ of them had dependences in daily activities (ADL) (Miller, Murray, \& Richard, et al, 2010).Paralysis and mental problems conditions, caused the difficulties for stroke patients to do ADL such as eating, dressing, and personal hygiene. Patient's hygiene is the primary responsibility of a nurse. Bathing is one component in personal hygiene that aims to maintain cleanliness, prevent the onset of disease, and Healthcare Associated Infections (HAIs) (Saputra, 2013).

Based on the observation by Yusuf, Herman, Aminah, et al (2017) found that $72 \%$ of all patients treated in neurology wardin Wahidin Sudirohusodo Hospital fell on moderate dependence and total dependence with Bartel Index 1-11. In otherpatient's ADL needs was assisted by nurses and families. All this time,conventional bathing with a basin and water has become a standard to the bedrest patients. But, the study by Toth et al (2017), bathing using a basin can be a reservoir for bacteria that can transmit an infections, especially in immunosuppressed patients and patients who badly sick. In addition, Kato (2017) found that hygiene care in beds became a heavy workload for nurses because it was tiring, requiring intense physical activity, and it took a long time.

One of the alternative method developed to reduce the things above was the Disposable Bed Bathing (DBB) . This method used washcloths (a soft and hygienic disposable tissue containing water, cleansing soap, moisturizers and antiseptics that can kill bacteria and fungi) to the patient for bathing procedures (Hortsman, 2014). The use of DBB is proven to reduce the number of bacteria in the skin compared to conventional bathing methods (Larson, et al, 2004). DBB didnot affect the skin's moisture and $\mathrm{PH}$, so it could maintained the skin integrity and reduced lesions on the skin (Gillis et al, 2015; Schoonhovenet al., 2015).

Although a multiple studies have shown the using of DBB as a positive and effective for enhance health outcomes, but in the patients comfort and nurse's perception context there is a paucity of literature and evidence. Therefore, it is relevant to conduct this study. This research aimed to determine the effect of disposable bed bathing method on Nurse satisfaction and the comfort of stroke patients at public hospital in Makassar.

\section{METHODS}


The Effect of Disposable Bed Bathing (DBB) on Nurse.... (Titi Iswanti Afelya et.al)

The design in this research was quasiexperimental with post-test with control group design. There were 60 respondents from a public hospital in Makassar participated in this study and divided into two groups; intervention group and the control group. There were 5 (five) data collection tools that used in this study. They were table of content which containing respondents' demographic data, nurse satisfaction questionnaire, comfort level questionnaire, patient dependency level assessment, and implementation observation sheet (checklist) of disposable bed bathing procedures. The comfort level questionnaire is a modification of the level of comfort according to Kolcaba, so that the validity and reliability of the instrument is tested before the research is conduct, the comfort quistionnaire from the 48-item including physical, psychospiritual, socio-cultural and environmental comfort . Researchers used Bartel index instrumentsfor screening the level of dependence (patients using standard). Data collected by observers (enumerators) who have been given training, then carried out the same perception between researchers and enumerators (test reliability) and tested using the kappa test.

Data was analyzed using the descriptive (frequency, mean, and standard deviation) and infrential statistics (Independent $\mathrm{t}$-test). All analyses were performed in SPSS 18.

Ethical clearance was obtained from the Research Ethics Commitee Faculty of Medicine, Hasanuddin University. All participants received through information regarding the study, their rights and privacy before signing the informed consent.

\section{RESULTS}

The number of samples in this study was 40 patients and 20 nurses in neurology ward. The study began by giving a informed consent to participate in the study. The intervention group was given DBBfor five days, and the control group was received the conventional bathing method also for five days.

Table 1 Distribution of Respondents by Sex, Education Level, Age on Stroke Patients in Neurology Ward of Wahidin Sudirohusodo Hospital Makassar, June - September 2018

\begin{tabular}{llcc}
\hline & \multirow{2}{*}{ Characteristics of Gender } & \multicolumn{2}{c}{$\mathbf{n = 4 0 ( 1 0 0 \% )}$} \\
\cline { 3 - 4 } & (Intevention Group) & 9 & $\mathbf{f}(\mathbf{\%})$ \\
\hline Male & (Control Group) & 7 & 22.5 \\
\hline Female & (Intevention Group) & 11 & 17.5 \\
\hline & (Control Group) & 13 & 27.5 \\
\hline
\end{tabular}

\begin{tabular}{llcc}
\hline \multirow{2}{*}{ Characteristics of Education Level } & \multicolumn{2}{c}{$\mathbf{n = 4 0 ( 1 0 0 \% )}$} \\
\cline { 3 - 4 } & & & $\mathbf{f}(\mathbf{\%})$ \\
\hline Elementary School & (Intevention Group) & 6 & 15 \\
\hline & (Control Group) & 4 & 10 \\
\hline Junior High School & (Intevention Group) & 7 & 17.5 \\
\hline & (Control Group) & 6 & 15 \\
\hline High School & (Intevention Group) & 5 & 12.5 \\
\hline College & (Control Group) & 7 & 17.5 \\
\hline & (Intevention Group) & 2 & 5.5 \\
& (Control Group) & 3 & \\
\hline
\end{tabular}




\begin{tabular}{lccc}
\hline \multicolumn{2}{c}{ Characteristics of Age } & \multicolumn{2}{c}{$\mathbf{n = 4 0 ( 1 0 0 \% )}$} \\
\hline Mean & SD & Min-Max \\
\hline Intevention Group & 64,21 & 7,46 & $40-76$ \\
\hline Control Group & 62,94 & 7,35 & $48-73$ \\
\hline
\end{tabular}

Table 2Analysisof the DBB Method on Nurse Satisfaction and Patient'sComfort in Neurology Ward of Wahidin Sudirohusodo Hospital Makassar, June - September 2018

\begin{tabular}{|c|c|c|c|c|}
\hline \multirow{2}{*}{\multicolumn{2}{|c|}{ Nurse Satisfaction }} & \multicolumn{3}{|c|}{$\mathrm{n}=40(100 \%)$} \\
\hline & & & $f(\%)$ & $P$ value \\
\hline \multirow[t]{2}{*}{ Satisfied } & (Intevention Group) & 17 & 42.5 & \multirow{4}{*}{0.029} \\
\hline & (Control Group) & 5 & 12.5 & \\
\hline \multirow[t]{2}{*}{ Dissatisfied } & (Intevention Group) & 3 & 7.5 & \\
\hline & (Control Group) & 15 & 37.5 & \\
\hline \multirow{2}{*}{\multicolumn{2}{|c|}{ Patient's Comfort Status }} & \multicolumn{3}{|c|}{$\mathrm{n}=40(100 \%)$} \\
\hline & & & $f(\%)$ & P value \\
\hline \multirow[t]{2}{*}{ Comfort } & (Intevention Group) & 10 & 25 & \multirow{4}{*}{0.063} \\
\hline & (Control Group) & 13 & 32.5 & \\
\hline \multirow[t]{2}{*}{ Uncomfort } & (Intevention Group) & 10 & 25 & \\
\hline & (Control Group) & 7 & 17.5 & \\
\hline
\end{tabular}

Table 1 describes the demographics characteristics of respondents. Distribution of respondents by sex is $9(22.5 \%)$ was male and female $11(27.5 \%)$ in the intervention group. Whereas the majority of respondents werefemale in both groups. The distribution of education level found that the highest number of respondents in intervention group were junior high school 7 people (17.5\%), while for elementary, high school and college are $15 \%$, $12.5 \%$ and $5 \%$ ). While in the control group, the most were in high school education $(17.5 \%)$.The results showed that the average age of respondents in the intervention group was 64.21 years, with the youngest age 40 years and the highest 76 years. Whereas in the control group the average age of respondents was 62.94 years, with the youngest age 48 years and the highest was 73 years.

Table 2 explains the result of $p$ value of the DBB effect on nurse satisfaction and patient's comfort. $\mathrm{P}$ value of nurse satisfaction is 0.029 meaning that there is an effect of DBB. And $\mathrm{p}$ value 0.063 on patient comfort, that there is no effect of disposable bed bath on patient comfort.

\section{DISCUSSIONS}

The findings of this research elucidated that DBB facilitates the work of nurses in bathing patients, but does not provide comfort to patients. El-Saoussi \& Asfour's study in 2016, stated that $79 \%$ of nurses prefer disposable bed bathing (DBB) methods compared to conventional bathing patients with consideration of workload and easiness of equipment used. Other studies conducted by (Horstmann, et al, 2015) found that bathing with disposable bed baths was cheaper in terms of cost, duration was faster than bathing using a basin so that nurses felt more satisfied.

Nurses in providing professional nursing care at the Hospital are expected can get the satisfaction in their work. Satisfaction in work is an emotional response to various aspects (Kreitner, 2014). Various factors that can affect a person's satisfaction in work, one of which is satisfaction with the work itself. 
Satisfaction which is done is a reflection of feelings about the current job conditions, including whether the work is challenging, interesting, respectful, and requires skills, compared to jobs that are repetitive (Juliansyah, 2013).Bathing the patient is the duty of the nurse in compliance daily personal hygiene needs. Kato (2017) found that hygiene care in beds became a heavy workload for nurses because their work was tiring, requiring intense physical activity, and it takes a long tim, hygiene care in bed is considered a potential workload for nurses because the work is tiring; requires intense physical effort, and also some patients must be provided with bedside care during certain shifts. It madethe nurses have a few time to care other patients.

In the other hand, disposable as one of the choices in implementing nursing interventions. Disposable bed bath method is a bathing method using disposable washcloths that are soft and very strong when wet, hygienic because they contain water and cleansing soap, moisturizers and antiseptics that can kill bacteria and fungi (Hortsman, 2014).So it can be alternate for nurses.

The result of this study showed that the disposable bed bathing method increased the nurse satisfaction. This finding was consistent with study of Yusuf, et al (2017) about the experience of nurses in bathing patients using disposable bed bathing (DBB) compared to conventional methods, revealed that nurses felt more satisfied using DBB because the time needed was shorter, practical so that they could carry out other nursing care many patients optimally.

A futher revealing aspect of this study is that the comfort level of the patient, DBB did not affect to the comfort perceived. Comfort is influenced by the prior experience (Alligood \& Tomey, 2010). So far the patient's experience in hospital is bathed using water and a basin, so this condition can affect the perceived comfort

Patient's choice of an intervention is determined by perceived comfort, which there are the differences perceptions of comfort among them. Comfort is a pleasant sensation that gives satisfaction to a person, a pleasant feeling both physically and psychologically when using something (Silva et al, 2012; Dear et al, 2013; Pinto et al, 2012). Holistic comfort consists of physical comfort, psycho-spiritual comfort, socio-cultural comfort, and environmental comfort (Kolcaba, 2013).

When the nursing care provided aims to create comfort, then the first thing the nurse have to do is conduct the examinationof need for relief, ease and transcendence as a basis for developing and implementing comfort interventions in patients (Kolcaba \& Dimarco, 2005). The difference between the three comfort stages indicates that the nurse must consider all three in designing and organizing the environment, making nursing goals, and choosing the right intervention for the three components. The therapeutic context places the patient in the main position, provides an intervention according to the patient's condition, for example in Patient with chronic illness, the environment is designed with quiet conditions not much stimulus, a sign of patient discomfort observed every time, which aims to reduce discomfort (Kolcaba, 1991).

The increased of comfort encourage habits and future-oriented goals that are the expectations of the nursing process. Increaseing comfort felt by patients, moves towards better behavior. This behavior became the reason for the implementation of comfort measures that will be negotiated with patients (Kolcaba, 1991: Alligood \& Tomey, 2010: Wilson \& Kolcaba, 2004).

\section{CONCLUSIONS}

Disposable bed bath method can increase nurse satisfaction in bathing patients but there is no effect on patient comfort, because bathing habits using water is an inherent culture for patients.

\section{REFERENCES}

Aligood and Tomey. (2010).Nursing theorist and their work.St.Louis : Mosby Elsevier. 
Jurnal INJEC Vol. 3 No. 2 Desember 2018: 109-112

Powers J, Fortney S. 2014. Bed baths : Much more than a basic nursing task. Wound \&Skin Care.

El-Soussi, A.H, Asfour, H.I. 2016. Examining BedBath Practices of critically ill patients. Journal of nursing education and practice.

Kolcaba, K., Tilton, C, \& Drouin, C. (2006). Comfort theory: A unifying framework to enhance the practice environment. Journal of Nursing Administration, 36(11), 538544.

Kolcaba, K., \& DiMarco, M. A. (2005). Comfort theory and its application to pediatric nursing. Pediatric Nursing, 31(3), 187194.

Wilson L \& Kolcaba K. 2004. Practical Application of Comfort Theory in the Perianasthesia Setting. American Society of PeriAnesthesia Nurses.

Kreitner, Robert., dan Angelo Kinicki. 2014. Perilaku Organisasi. Jakarta: Salemba.

Juliansyah. 2013. Penelitian Ilmu Manajemen, Tinjauan Filosofis dan Praktis. Jakarta:

Kencana 